\title{
First Record of Wide-Eyed Flounder (Bothus podas Delaroche, 1809) in Saroz Bay (Northern Aegean Sea, Turkey)
}

\section{Özgür Cengiz ${ }^{1, a, *}$, Şükrü Şenol Paruğ $\breve{g}^{2, b}$, Bayram Kızllkaya ${ }^{3, c}$}

${ }^{1}$ Fisheries Faculty, Van Yüzüncü Yll Üniversitesi, 65080 Van, Turkey

${ }^{2}$ Fisheries Faculty, Kastamonu University, 37200 Kastamonu, Turkey

${ }^{3}$ Faculty of Marine Science and Technology, Çanakkale Onsekiz Mart University, 17100 Çanakkale, Turkey

*Corresponding author

\begin{tabular}{l|l}
\hline A R T I C L E I N F O & A B S T R A C T \\
\hline Research Article & $\begin{array}{l}\text { A single specimen of the wide-eyed flounder (Bothus podas Delaroche, 1809) was caught using the } \\
\text { trammel nets by fishermen on 15 May 2017 in İbrice Bight (Saroz Bay). This paper represents the } \\
\text { first record of B. podas for Saroz Bay. }\end{array}$
\end{tabular}

Received : 22/02/2019

Accepted : 15/04/2019

Keywords:

Bothus podas

Wide-eyed flounder

Saroz Bay

Northern Aegean Sea

Turkey

Türk Tarım - Gıda Bilim ve Teknoloji Dergisi 7(6): 899-902, 2019

\section{Pisi Balığının (Bothus podas Delaroche, 1809) Saroz Körfezindeki (Kuzey Ege Denizi, Türkiye) İlk Kaydı}

\begin{tabular}{|c|c|}
\hline M A K A L E B İ L G İ S İ & Ö Z \\
\hline Araştırma Makalesi & $\begin{array}{l}\text { Bir adet pisi balığı (Bothus podas Delaroche, 1809), } 15 \text { Mayıs } 2017 \text { tarihinde İbrice Koyu’nda (Saroz } \\
\text { Körfezi), balıkçılar tarafından fanyalı ağlar ile yakalanmıştır. Bu çalışma Saroz Körfezi için } B \text {. } \\
\text { podas'un ilk kaydını sunmaktadır. }\end{array}$ \\
\hline $\begin{array}{ll}\text { Geliş } & : 22 / 02 / 2019 \\
\text { Kabul } & : 15 / 04 / 2019\end{array}$ & \\
\hline $\begin{array}{l}\text { Anahtar Kelimeler: } \\
\text { Bothus podas } \\
\text { Pisi balı̆̆ } 1 \\
\text { Saroz Körfezi } \\
\text { Kuzey Ege Denizi } \\
\text { Türkiye }\end{array}$ & \\
\hline $\begin{array}{l}\text { a@ozgurcengiz17@gmail.com } \\
\text { c_ayram342001@yahoo.com }\end{array}$ & $\begin{array}{l}\text { (D https://orcid.org/0000-0003-1863-3482 } \\
\text { (iD https://orcid.org/0000-0002-3916-3734 }\end{array}$ \\
\hline
\end{tabular}




\section{Introduction}

The wide-eyed flounder (Bothus podas Delaroche, 1809) is a small bothiid species usually living on shallow soft and mixed sediments on the continental shelf to a depth of about $400 \mathrm{~m}$ (Torchio, 1962; Nash et al., 1991). This species is distributed in the Mediterranean and in the Eastern Atlantic, from the Gulf of Cadiz to Angola, including Madeira, Cape Verde and the Canary Islands (Göthel, 1992).

Bothus podas has no commercial value but appears to be of ecological importance in these relatively rare shallow-water, sandy-bottom areas (Morato et al., 2007). It is a diurnal predator, usually burrowing partially or almost entirely in sand or mud (Darnaude et al., 2001). The studies on the feeding habits of this species report that it feeds mainly on benthic invertebrates like molluscs, polychaetes, crustaceans and sea urchins (Nash et al., 1991), but also on small benthic fishes (Azevedo, 1995; Darnaude et al., 2001).

The social structure of the wide-eyed flounder is haremic. Both sexes are territorial throughout the year.
Adult males defend large territories, which include several smaller female territories. During the reproductive season, which lasts from May to August in the Mediterranean Sea, territorial males court and mate only with females in their territories (Carvalho et al., 2003; Esposito et al., 2009). The present study is the first record of the wide-eyed flounder (Bothus podas Delaroche, 1809) in the Saros Bay (Northern Aegean Sea, Turkey).

\section{Material and Methods}

A single specimen of Bothus podas (Figure 1) was caught using the trammel nets by fishermen on 15 May 2017 in İbrice Bight (Saroz Bay) (Figure 2) at a depth of about $15 \mathrm{~m}$. The specimen was identified based on Mater et al. (2009), photographed and some meristic characters were measured. And then, it was fixed and preserved in $6 \%$ formalin solution.

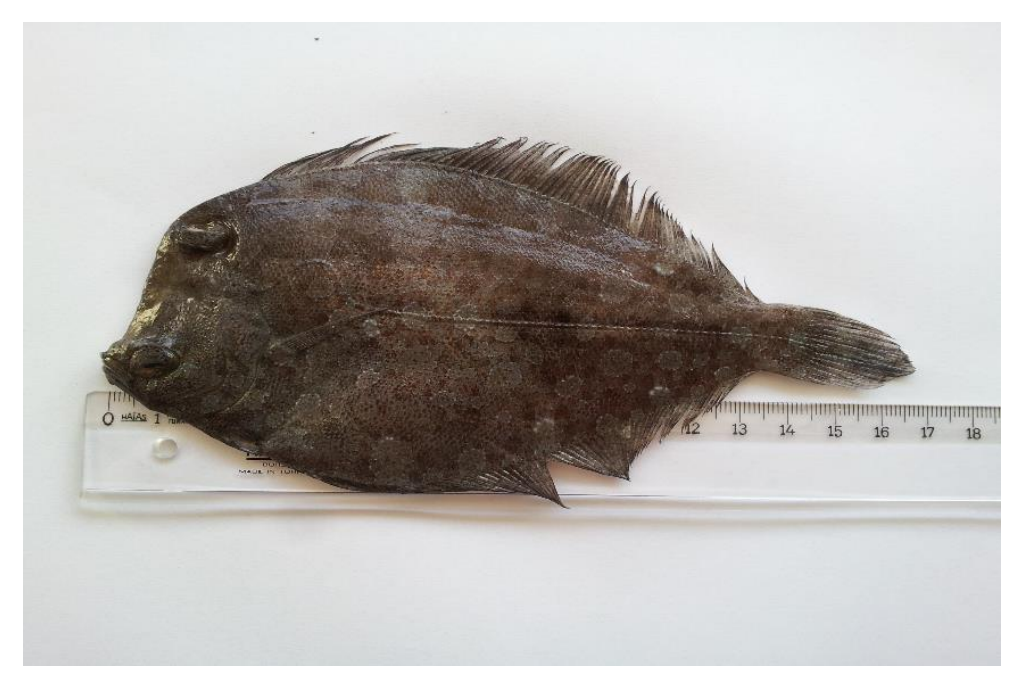

Figure 1 Bothus podas captured in İbrice Bight, Saroz Bay

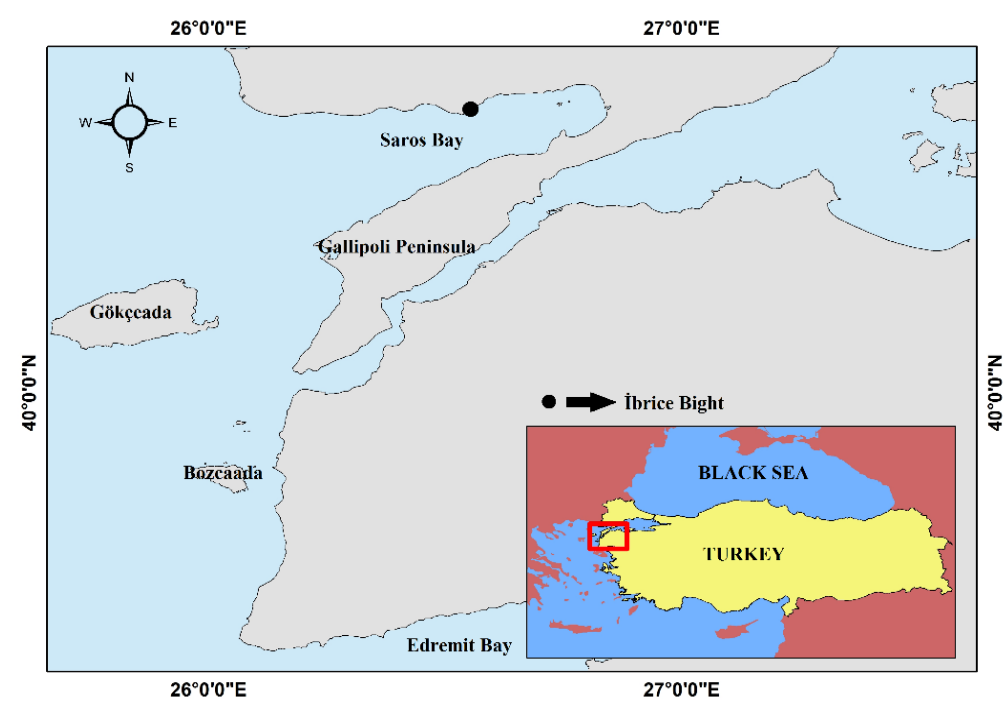

Figure 2 İbrice Bight where Bothus podas was captured (indicated by a full dot) 


\section{Results and Discussion}

Saroz Bay, which is situated in the Northeastern Aegean Sea, is connected to the North Aegean with a depth of approximately $600 \mathrm{~m}$ to the west. The shelf extends at a water depth of $90-120 \mathrm{~m}$. The length of the bay is about 61 $\mathrm{km}$ and the width at the opening to the Aegean Sea is about $36 \mathrm{~km}$ (Eronat and Sayın, 2014). As Saroz Bay had been closed to bottom trawl fishing since 2000 (Cengiz et al., 2011) and no industrial activity was prevalent in the area (Sarı and Çağatay, 2001), the bay can be considered as a pristine environment (Cengiz et al., 2013). The total length of captured specimen of Bothus podas was $17.0 \mathrm{~cm}$ and total weight was $53.0 \mathrm{~g}$. The specimen presented following meristic characters; dorsal fin rays 85 , pectoral fin rays 9 , anal fin rays 70, pelvic fin rays 6 and line lateral numbers of scale 81 . The body is flat and its shape is elongated oval. With a open tail fin, it looks like a shell. The eyes are very wide and the mouth is vertical. In addition, the entire fish is asymmetric.

As to Turkish waters, the wide-eyed flounder has been reported by Özaydın et al. (2007) in İzmir Bay and by Bilge et al. (2014) in Southern Aegean. Although several studies on fish communities have been done in the Saroz Bay (Koç et al., 2004; İşmen et al., 2007; Özekinci et al., 2009; Altuğ et al., 2011; Cengiz et al., 2011; Keskin et al., 2011a; 2011b), B. podas has never been caught or mentioned for this area. But, in the table that Çoker and Akyol (2018) submitted on the fish diversity of Saroz Bay, although they has shown the existence of species as if it existed in the Saroz Bay, the involved species has been reported by Keskin and Ünsal (1998), Karakulak et al. (2006), Keskin et al. (2013), Gönülal and Güreşen (2014), Altın et al. (2015) in Gökçeada Island, an area which is completely independent of the Saroz Bay.

In this connection, the faunal changes observed are related to climate change and water warming (Dulčić et al., 1999; Dulčić and Grbec, 2000). The climate change controls the rate of change in the geographical distribution of marine species or populations in the sea (Papaconstantinou, 2014). These changes may affect the status of the Turkish marine fauna and give rise to rare occurrences in Northern Aegean Sea (Cengiz, 2014; Cengiz and Tunçer, 2015).

\section{Conclusion}

There are no specific conservation measures in place for this species (IUCN, 2019). The captured single specimen of $B$. podas does not clearly indicate that there is an established population in Saroz Bay. At this juncture, this occurrence may be the base for future monitoring of possible spreading of the species.

\section{Acknowledgement}

The authors would like to thank the fisherman Engin TUNÇ and Semih KALE for their supports.

\section{References}

Altın A, Ayyıldız H, Kale S, Alver C. 2015. Length-weight relationships of 49 fish species from shallow waters of Gökçeada Island, Northern Aegean Sea. Turkish Journal of Zoology, 39: 1-5.
Altuğ G, Aktan Y, Oral M, Topaloğlu B, Dede A, Keskin Ç, İşinibilir M, Çardak M, Çiftçi PS. 2011. Biodiversity of the northern Aegean Sea and southern part of the Sea of Marmara, Turkey. Marine Biodiversity Records, 4: 1-17.

Azevedo JMN. 1995. Food web of the Azorean shallow water marine ichthyological communities: A guild approach. 1 Symposium of 'Fauna and Flora of the Atlantic Islands', Funchal, Madeira (Portugal), October 1993. Boletim do Museu Municipal do Funchal supplement, 4A: 29-53.

Bilge G, Yapıc1 S, Filiz H, Cerim H. 2014. Weight-length relations for 103 fish species from the Southern Aegean Sea, Turkey. Acta Ichthyologica et Piscatoria, 44: 263-269.

Carvalho N, Pedro A, Serrao Santos R. 2003. The haremic mating system and mate choice in the wide-eyed flounder, Bothus podas. Environmental Biology of Fishes, 66: 249-58.

Cengiz Ö, İşmen A, Özekinci U, Öztekin A. 2011. Saroz Körfezi (Kuzey Ege Denizi) balık faunası üzerine bir araştırma. Afyon Kocatepe Üniversitesi Fen Bilimleri Dergisi, 11: 31-37.

Cengiz Ö, Özekinci U, İşmen A, Öztekin A. 2013. Age and growth of the four-spotted megrim (Lepidorhombus boscii Risso, 1810) from Saros Bay (Northern Aegean Sea, Turkey). Mediterranean Marine Science, 14(1): 36-44.

Cengiz Ö. 2014. On occurrence of flying gurnard (Dactylopterus volitans Linnaeus, 1758) in the Gallipoli Peninsula (Northern Aegean Sea, Turkey). Turkish Journal of Agricultural and Natural Sciences, Special Issue 1: 1340-1342.

Cengiz Ö, Tunçer S. 2015. Second record of Atlantic lizardfish, Synodus saurus (Linnaeus, 1758), from the Northern Aegean Coast of Turkey. Acta Zoologica Bulgarica, 67: 447-450.

Çoker T, Akyol O. 2018. An evaluation on the fish diversity of Saroz Bay and Gökçeada Island (Northern Aegean Sea). Turkish Journal of Maritime and Marine Sciences, 4: 81-92.

Darnaude AM, Harmelin-Vivien ML, Salen-Picard C. 2001. Food partitioning among flatfish (Pisces: Pleuronectiforms) juveniles in aMediterranean coastal shallow sandy area. Journal of the Marine Biological Association, UK 81: 119-27.

Dulčić J, Grbec B, Lipej L. 1999. Information on the Adriatic ichthyofauna - effect of water warming? Acta Adriatica, 40: $33-43$.

Dulčić J, Grbec B. 2000. Climate change and Adriatic ichthyofauna. Fisheries Oceanography, 9: 187-191.

Eronat C, Sayın E. 2014. Temporal evolution of the water characteristics in the bays along the eastern coast of the Aegean Sea: Saros, İzmir, and Gökova bays. Turkish Journal of Earth Sciences, 23: 53-66.

Esposito V, Battaglia P, Castriota L, Finoia MG, Scotti G, Andaloro F. 2009. Diet of Atlantic lizardfish, Synodus saurus (Linnaeus, 1758) (Pisces: Synodontidae) in the central Mediterranean Sea. Scientia Marina, 73(2): 369-376.

Gönülal O, Güreşen SO. 2014. A list of macrofauna on the continental shelf of Gökçeada Island (northern Aegean Sea) with a new record (Gryphus vitreus Born, 1778) for the Turkish seas. Journal of Black Sea/Mediterranean Environment, 20(3): 228-252.

Göthel H. 1992. Fauna marina del Mediterra'neo. Barcelona: Ediciones Omega SA. 319 pages.

IUCN 2019. The IUCN Red List of Threatened Species 2015: e.T198725A15539590. http://dx.doi.org/10.2305/IUCN.UK.20154.RLTS.T198725A15539590.en. Accessed 22 February 2019.

İşmen A, Özen Ö, Altinağaç U, Özekinci U, Ayaz A. 2007. Weight-length relationships of 63 fish species in Saros Bay, Turkey. Journal of Applied Ichthyology, 23: 707-708.

Karakulak FS, Erk H, Bilgin B. 2006. Length-weight relationships for 47 coastal fish species from the northern Aegean Sea, Turkey. Journal of Applied Ichthyology, 22: 274-278.

Keskin Ç, Ünsal N. 1998. The fish fauna of Gökçeada Island, NE Aegean Sea, Turkey. Italian Journal of Zoology, 65 (Suppl.): 299-302. 
Keskin C, Turan C, Ergüden D. 2011a. Distribution of the demersal fishes on the continental shelves of the Levantine and North Aegean Seas (Eastern Mediterranean). Turkish Journal of Fisheries and Aquatic Sciences, 11: 413-423.

Keskin C, Ordines F, Guijarro B, Massuti E. 2011b. Comparison of fish assemblages between the Sea of Marmara and the Aegean Sea (north-eastern Mediterranean). Journal of the Marine Biological Association of the United Kingdom, 91: 1307-1318.

Keskin Ç, Oral M, İnanmaz ÖE. 2013. Juvenile fish assemblages aroun Gökçeada Island (North Aegean Sea, Eastern Mediterranean): Posidonia oceanica (L.) Delile meadows, rocky and bare sand areas. In: Y. Aktan \& V. Aysel (eds), First International Workshop on Posidonia oceanica (L.) Delile on the coast of Turkey, 19-20 Sept., pp 144-152, Gökçeada, TUDAV Publication No. 39.

Koç HT, Aka Z, Cakır DT. 2004. An investigation on fishes of Saros Bay (Northern Aegean Sea). Journal of the Institute of Science and Technology of Balıkesir University, 6: 4-12.

Mater S, Kaya M, Bilecenoğlu M. 2009. Marine Fishes of Turkey (4th press), Ege University Fisheries Faculty Publishings, No. 68, İzmir. (In Turkish).
Morato T, Afonso P, Carvalho N, Lourinho P, Santos RS, Krug HM, Nash RDM. 2007. Growth, reproduction and recruitment patterns of the wide-eyed flounder, Bothus podas Delaroche (Pisces: Bothidae), from the Azores. Marine Biology Research, 3: 403-411.

Nash RDM, Geffen AJ, Santos RS. 1991. The wide-eyed flounder, Bothus podas, Delaroche, a singular flatfish in varied shallow-water habitats of the Azores. Netherland Journal of Sea Research, 27: 367-373.

Özaydın O, Uçkun D, Akalın S, Leblebici S, Tosunoğlu Z. 2007. Length-weight relationships of fishes captured from Izmir Bay, Central Aegean Sea. Journal of Applied Ichthyology, 23: 695-696.

Özekinci U, Cengiz Ö, İşmen A, Altinağaç U, Ayaz A. 2009. Length-weight relationships of thirteen flatfishes (Pisces: Pleuronectiformes) from Saroz Bay (North Aegean Sea, Turkey). Journal of Animal and Veterinary Advances, 8(9): 1800-1801.

Papaconstantinou C. 2014. Fauna Graeciae. An updated checklist of the fishes in the Hellenic Seas. Monographs on Marine Sciences, 7, Athens 2014, HCMR, 340 pp.

Sarı E, Çağatay MN. 2001. Distributions of heavy metals in the surface of the Gulf of Saros, NE Aegean Sea. Environment International, 26: 169-173.

Torchio M. 1962. Osservazioni sui Bothidae delle acque italiane (Pisces Pleuronectiformes). Bollettino Zoologico, 29: 66778. 